\title{
Effect of Organ Culture on Noradrenaline- Evoked Contraction, Calcium Signalling and TRPC Expression in Rat Mesenteric Artery
}

\author{
Khalid Tai $^{\mathrm{a}} \quad$ Greet Vandenberg $^{\mathrm{a}} \quad$ Marie-Christine Hamaide ${ }^{\mathrm{b}}$ Maurice Wibo ${ }^{\mathrm{b}}$ \\ Nicole Morel ${ }^{\mathrm{a}}$ \\ a Laboratories of Cellular Physiology and ${ }^{\mathrm{b}}$ Experimental Pharmacology, Université catholique de Louvain, \\ Brussels, Belgium
}

\section{Key Words}

Mesenteric artery $\cdot$ Organ culture $\cdot$ Contractile phenotype $\cdot$

$\mathrm{Ca}^{2+}$ signal $\cdot$ Noradrenaline $\cdot$ Transient receptor potential

canonical $\cdot$ Src kinase

\begin{abstract}
The aim of this study was to explore the changes evoked by organ culture in the signalling pathways activated by noradrenaline in rat resistance mesenteric artery. Contractile responses and calcium signalling were significantly more sensitive to noradrenaline in arteries cultured for $48-72 \mathrm{~h}$ in the absence of growth factors compared to fresh arteries. Both calcium release activated by noradrenaline in calcium-free solution and calcium entry measured after the addition of external calcium were higher in cultured arteries than in fresh tissue. Blockers of non-selective cation channels (SKF96365, flufenamic acid, $\mathrm{Gd}^{3+}$ ) more potently inhibited noradrenaline contraction in cultured arteries than in fresh ones. The src kinase inhibitors genistein or PP2 normalised the increased contraction and the increased calcium release evoked by noradrenaline in cultured arteries. In cultured arteries, $\operatorname{trpc} 1$ (transient receptor potential canonical 1) mRNA expression was decreased by $47 \pm 8 \%(n=5, p<0.05)$, while trpc 6 mRNA expression was increased by $92 \pm 24 \%$ ( $n=5$, $\mathrm{p}<0.05$ ) in comparison with non-cultured arteries. Immunofluorescence analysis of protein expression confirmed the
\end{abstract}

up-regulation of TRPC6 protein after culture. These results indicate that mesenteric artery culture results in src kinasedependent increase in the responses to noradrenaline and in a change in cation channel activity, which could contribute to the increased contraction.

Copyright $\odot 2009$ S. Karger AG, Basel

\section{Introduction}

Organ culture of isolated artery is frequently used as an experimental model for vascular pathologies characterised by growth and proliferation of vascular smooth muscle cells (VSMC), such as atherosclerosis, hypertension or balloon injury. Arteries cultured in the absence of added growth factors maintain their contractile phenotype for several days $[1,2]$. However, culture has been reported to evoke diverse cellular changes. Cultured porcine coronary artery displays increased contractile and $\mathrm{Ca}^{2+}$ responses to endothelin-1, which are attributed to ETA receptors [3]. In rat basilar artery, organ culture increases the contraction to endothelin-1, an effect associated with the up-regulation of ETB receptor without change in ETA receptor subtype [4]. Organ culture of rat mesenteric artery has been reported to enhance the contraction evoked by noradrenaline, and to increase $\alpha 1_{\mathrm{A}^{-}}$ adrenoceptor mRNA expression, through a signalling

\section{KARGER}

Fax +41613061234 E-Mail karger@karger.ch www.karger.com
(C) 2009 S. Karger AG, Basel

1018-1172/09/0464-0353\$26.00/0

Accessible online at:

www.karger.com/jvr
Prof. Nicole Morel

Laboratoire de Physiologie Cellulaire

Université catholique de Louvain 5540

Avenue Hippocrate 55, BE-1200 Bruxelles (Belgium)

Tel. +32 2764 5549, Fax +32 2764 5580, E-Mail nicole.morel@uclouvain.be 
pathway involving PKC and ERK1/2 [5]. Organ culture of vascular tissue also evokes changes in the $\mathrm{Ca}^{2+}$ handling, as suggested by the increase in store-operated $\mathrm{Ca}^{2+}$ entry in cultured cerebral arteries, which has been reported to be related to the increased expression of TRPC1 (transient receptor potential canonical 1) [1]. The latter observation is of particular interest since calcium is known to play a major role in cell proliferation.

The aim of the present study was to characterize the effect of $48 \mathrm{~h}$ of organ culture on the $\mathrm{Ca}^{2+}$ signal and contraction in response to noradrenaline in resistance mesenteric arteries of the rat. We also investigated the effect of culture on the signalling pathways involved in these responses. Vasoconstriction of peripheral arteries in response to the sympathetic neurotransmitter noradrenaline plays an important role in the regulation of arterial blood pressure. The activation of the $\alpha 1$-adrenoreceptor leads to the production of IP3 and diacylglycerol (DAG), the release of internal $\mathrm{Ca}^{2+}$ stores and $\mathrm{Ca}^{2+}$ influx. The experiments were designed to determine whether culture affects noradrenaline-activated $\mathrm{Ca}^{2+}$ signalling in resistance mesenteric arteries, in relation to contractile responses. Results indicated that organ culture of mesenteric artery increased its contractile sensitivity to noradrenaline and to the $\mathrm{G}$ protein activator $\mathrm{AlF}_{4}$, without changing the maximum level of contraction. Pharmacological and molecular tools were used to investigate the molecular basis of this effect.

\section{Material and Methods}

\section{Organ Culture}

All protocols were in accordance with institutional guidelines for the use of experimental animals. The rats were anesthetised and sacrificed by decapitation at a body weight of 150-200 g. The mesenteric artery was rapidly removed and immersed in phosphate-buffered saline (PBS; composition, in mmol/l: $\mathrm{NaCl} \mathrm{136.9;}$ $\mathrm{KCl}$ 2.7; $\mathrm{KH}_{2} \mathrm{PO}_{4} 1.5 ; \mathrm{Na}_{2} \mathrm{PO}_{4} 8 ; \mathrm{pH}$ 7.4, with Tris). Third-order branches of the superior mesenteric artery (mean internal diameter normalised at $100 \mathrm{~mm} \mathrm{Hg}$ was $304 \pm 5.7 \mu \mathrm{m}$ ) were carefully cleaned of all fat and connective tissue, and the endothelium was gently removed using a sterile hair. Segments, about $2 \mathrm{~mm}$ in length, were either immediately used for contraction or kept at $-80^{\circ} \mathrm{C}$ for further analysis, or cultured for 24,48 or $72 \mathrm{~h}$ in an incubator at $37^{\circ} \mathrm{C}$ with humidified $5 \% \mathrm{CO}_{2}$ in Dulbecco's modified Eagle's medium without serum, with 50 units $/ \mathrm{ml}$ penicillin, $50 \mu \mathrm{g} / \mathrm{ml}$ streptomycin and $2 \mathrm{mmol} / \mathrm{l}$ glutamine.

\section{Measurement of Contractile Response}

Freshly isolated (condition $0 \mathrm{~h}$ ) or cultured segments of mesenteric artery were mounted in a wire myograph (Model 500A, Danish Myo Technology A/S, Aarhus, Denmark) filled with phys- iological solution (composition, in mmol/l: $\mathrm{NaCl} 122 ; \mathrm{NaHCO}_{3}$ $15 ; \mathrm{KCl} 5.9 ; \mathrm{CaCl}_{2}$ 1.25; $\mathrm{MgCl}_{2}$ 1.2; glucose 11 ) bubbled with $95 \%$ $\mathrm{O}_{2} / 5 \% \mathrm{CO}_{2}$ and maintained at $37^{\circ} \mathrm{C}$. The vessel was set at a tension equivalent to that generated at 0.9 times the diameter of the vessel at $100 \mathrm{~mm} \mathrm{Hg}$. After an equilibration period, each preparation was contracted by changing the physiological solution in the bath to a depolarizing $100 \mathrm{mmol} / \mathrm{l} \mathrm{KCl}$ solution (composition, in mmol/l: $\mathrm{NaCl} 27 ; \mathrm{KCl} \mathrm{100;} \mathrm{NaHCO}_{3} 15 ; \mathrm{MgCl}_{2}$ 1.25; $\mathrm{CaCl}_{2}$ 1.25; glucose 11). Effective removal of the endothelium was tested by measuring the relaxation evoked by acetylcholine $(1 \mu \mathrm{mol} / \mathrm{l})$. After the KCl-evoked contraction, the $\mathrm{NO}$ synthase inhibitor $\mathrm{N \omega}$ nitro-L-arginine (L-NNA; $100 \mu \mathrm{mol} / \mathrm{l}$ ) was added to the physiological solution.

Arteries were thereafter stimulated by cumulative additions of noradrenaline ( $10 \mathrm{nmol} / \mathrm{l}$ to $10 \mu \mathrm{mol} / \mathrm{l}$, final concentration). After washout, the vessels were incubated with inhibitors or equal volume of solvent for $30 \mathrm{~min}$, and the noradrenaline concentrationresponse curve was resumed in the continuous presence of the inhibitor/solvent. Contractile response to noradrenaline was expressed either in $\mathrm{mN} / \mathrm{mm}$ (by dividing the force developed by the artery by twice the length of the artery segment) or as a percentage of the maximum response recorded during the first stimulation.

\section{Measurement of Cytosolic $\mathrm{Ca}^{2+}$ Concentration and \\ Contractile Tension}

Freshly isolated or cultured mesenteric arteries were incubated for 3-3.5 h at room temperature in physiological solution (composition as above) containing $5 \mu \mathrm{mol} / \mathrm{l}$ fura- 2 acetoxymethylester (fura-2-AM) and 0.05\% Cremophor EL [6]. After the loading period, the arteries were mounted in a myograph continuously perfused with oxygenated physiological solution supplemented with L-NNA $(100 \mu \mathrm{mol} / \mathrm{l})$ at $37^{\circ} \mathrm{C}$. The myograph was part of a fluorimeter (CAF, Jasco, Tokyo, Japan) which allowed estimation of the $\mathrm{Ca}^{2+}$ signal. The muscle tone was measured using an isometric force transducer. Arteries were first stimulated with $100 \mathrm{mmol} / \mathrm{l} \mathrm{KCl}$ solution. After washout, arteries were incubated with or without inhibitor or solvent and stimulated with noradrenaline. To measure $\mathrm{Ca}^{2+}$ release evoked by noradrenaline, arteries were perfused with $\mathrm{Ca}^{2+}$-free solution prepared from physiological solution without $\mathrm{Ca}^{2+}$ supplemented with EGTA $(0.1 \mathrm{mmol} / \mathrm{l})$. At the end of the experiment, the fura-2- $\mathrm{Ca}^{2+}$ signal was calibrated: the maximum fluorescence ratio F340/F380 was measured in saturating calcium medium after addition of ionomycin $(10 \mu \mathrm{mol} / \mathrm{l})$ and the minimum ratio was obtained in the presence of EGTA $(10 \mathrm{mmol} / \mathrm{l})$. The $\mathrm{Ca}^{2+}$ signal was corrected for the autofluorescence measured at 340 and $380 \mathrm{~nm}$ after the addition of $\mathrm{MnCl}_{2}(5 \mathrm{mmol} / \mathrm{l})$. Cytosolic $\mathrm{Ca}^{2+}$ concentration was calculated as described previously [6,7]. Responses to noradrenaline were normalised to the response evoked by the high- $\mathrm{KCl}$ solution in the same artery segment.

\section{Total RNA Isolation}

Total RNA was isolated from freshly isolated and from cultured mesenteric arteries using the Trizol isolation reagent (Invitrogen), and treated with DNase I (Invitrogen). The RNA sample was additionally purified by ethanol precipitation and its concentration was determined by measuring absorbance at $260 \mathrm{~nm}$. 
Table 1. Oligonucleotide sequences of rat primers used for RT-PCR

\begin{tabular}{|c|c|c|c|c|}
\hline mRNA & Accession number & Orientation & Primer sequence $\left(5^{\prime}-3^{\prime}\right)$ & Amplicon, bp \\
\hline \multirow[t]{2}{*}{ rtrpc1 } & \multirow[t]{2}{*}{ NM_053558 } & \multirow{2}{*}{$\begin{array}{l}\text { forward } \\
\text { reverse }\end{array}$} & CTGTGGTATGAAGGGTTGGAAG & \multirow[t]{2}{*}{425} \\
\hline & & & GTGTCGTTGCTTTGCTGTTCAC & \\
\hline \multirow[t]{2}{*}{ rtrpc3 } & \multirow[t]{2}{*}{ NM_021771 } & forward & TGCTTGTGTTCAACGCCTCA & \multirow[t]{2}{*}{146} \\
\hline & & reverse & CCCGAGAACCCAGACCATAAT & \\
\hline \multirow[t]{2}{*}{ rtrpc4 } & \multirow[t]{2}{*}{ NM_053434 } & forward & CGTGGAAAAGGGGGACTATG & \multirow[t]{2}{*}{181} \\
\hline & & reverse & CGCATCGCCAACATAGACATTGAA & \\
\hline \multirow[t]{2}{*}{ rtrpc5 } & \multirow[t]{2}{*}{ NM_080898 } & forward & AACCTACTTCGGAGCCAATGTAC & \multirow[t]{2}{*}{158} \\
\hline & & reverse & CCGGATTTCACCTAACTCTACCTC & \\
\hline \multirow[t]{2}{*}{ rtrpc6 } & \multirow[t]{2}{*}{ NM_053559 } & forward & GTCGGTGGTCATCAACTACAATC & \multirow[t]{2}{*}{155} \\
\hline & & reverse & CCACATCCGCATCATCCTCAATT & \\
\hline \multirow[t]{2}{*}{ rtrpc7 } & \multirow[t]{2}{*}{ XM_225159 } & forward & ATCATCTCGGAAGGGCTGTAC & \multirow[t]{2}{*}{209} \\
\hline & & reverse & GCACCTCGGTAGTAGGAGTAC & \\
\hline \multirow[t]{2}{*}{ rpl } & \multirow[t]{2}{*}{ X06483 } & forward & AGGCACCAGTCGGACCGATA & \multirow[t]{2}{*}{159} \\
\hline & & reverse & GAAGCCGCTAGGCAGCATGT & \\
\hline
\end{tabular}

$\operatorname{trpc}=$ Transient receptor potential canonical; $\mathrm{rpl}=$ ribosomal protein $\mathrm{L} 32$.

\section{PCR Primers}

PCR primers for the genes chosen for classic PCR were designed based on published sequences in GenBank (table 1).

\section{Polymerase Chain Reaction}

DNase-treated RNA samples were reverse transcribed into cDNA by using Superscript II (Invitrogen). Reverse transcriptase-negative controls were prepared without the addition of SuperScript II to exclude the presence of contaminating genomic DNA. PCR reactions were performed using the AccuPrime ${ }^{\mathrm{TM}} \mathrm{Su}-$ perMix I (Invitrogen) with a tracer amount (approximately 25 $\mathrm{kBq})$ of $\alpha-{ }^{32} \mathrm{P}-\mathrm{dCTP}$ (Amersham) and primer pairs based on known rat trpc sequences specific for the different trpc isoforms (table 1). The Techne Progene PCR cycler was programmed to perform initial denaturation at $95^{\circ} \mathrm{C}$ for 5 min followed by 30 cycles for trpc and 24 for rpl32 (ribosomal protein L32) of denaturation at $95^{\circ} \mathrm{C}$ for $30 \mathrm{~s}$, annealing at $60^{\circ} \mathrm{C}$ for $30 \mathrm{~s}$, and extension at $68^{\circ} \mathrm{C}$ for $2 \mathrm{~min}$, followed by prolonged extension at $68^{\circ} \mathrm{C}$ for 10 min. PCR products were separated on polyacrylamide gels. The radiolabelled bands in dried gels were detected and quantitated by means of a Cyclone Storage Phosphor System (Perkin-Elmer, Boston, Mass., USA). mRNA expression was normalised to the level of expression of rpl32 mRNA.

\section{Immunohistochemistry}

After dissection or culture, mesenteric segments were immediately washed twice in PBS (containing, in mmol/l: $\mathrm{NaCl} 137$; $\mathrm{KCl}$ 6; $\mathrm{CaCl}_{2} 2 ; \mathrm{MgCl}_{2}$ 1.2; glucose 10; HEPES 10; pH 7.4, with Tris), $\mathrm{pH} 7.3$, opened longitudinally and fixed with $4 \%$ formaldehyde in PBS for $10 \mathrm{~min}$. Arteries were then permeabilised by treatment with $1 \%$ Triton X-100 for 15 min.

Arteries were incubated for $60 \mathrm{~min}$ in PBS containing 5\% bovine serum albumin at $37^{\circ} \mathrm{C}$, followed by incubation in PBS containing $1 \%$ bovine serum albumin and rabbit polyclonal antiTRPC6 (Alomone, Jerusalem, Israel) at 1:250 dilution. After washing with PBS, segments were treated with Alexa 568 antirabbit IgG (Molecular Probes) at 1:1,000 and TO-PRO-3 (1 $\mu \mathrm{mol} / \mathrm{l}$, Molecular Probes) for DNA staining, washed again and placed luminal-side up on a glass slide and mounted in Mowiol (Calbiochem). Arteries were then visualised using a Zeiss Axiovert microscope coupled to a MRC-1024 confocal scanning laser imaging system (BioRad). In each artery, 10 optical sections of $238 \mu \mathrm{m}^{2}$ were taken every 0.5 microns on the z-axis. The average pixel fluorescence value was calculated using the formula:

$$
\text { Average }=\frac{\sum \mathrm{i}(\mathrm{p})}{\mathrm{n}(\mathrm{p})}(\text { I.U./pixel }),
$$

where $i(p)$ is the intensity of a pixel and $n(p)$ is the number of pixels.

Drugs Used

PD 98059, RHC-80267, GF-109203, PP2, genistein and fura-2 acetoxymethylester (fura-2-AM) were purchased from Calbiochem. Gö 6976, flufenamic acid and $\mathrm{GdCl}_{3}$ were obtained from Sigma. $\mathrm{AlF}_{4}$ was produced by the combination of $5 \mathrm{mmol} / \mathrm{l}$ sodium fluoride $(\mathrm{NaF})$ and $30 \mathrm{mmol} / \mathrm{l}$ aluminium chloride $\left(\mathrm{AlCl}_{3}\right)$. Stock solutions of PP2, genistein, Gö 6976, RHC-80267, GF109203 and PD 98059 were prepared in DMSO at $10 \mathrm{mmol} / 1 . \mathrm{Gd}^{3+}$ and SKF-96365 were dissolved in water. Flufenamic acid was dissolved in ethanol.

\section{Statistical Analysis}

Data are presented as means \pm SEM. The noradrenaline concentration producing $50 \%$ of the maximal effect (EC50), or $\mathrm{pD} 2$ value $(-\log E C 50)$, was calculated by non-linear curve fitting (Prism, GraphPad). Log values were used for statistical analysis. Comparisons were tested with Student's t test or ANOVA. $\mathrm{p}<0.05$ was considered significant. 


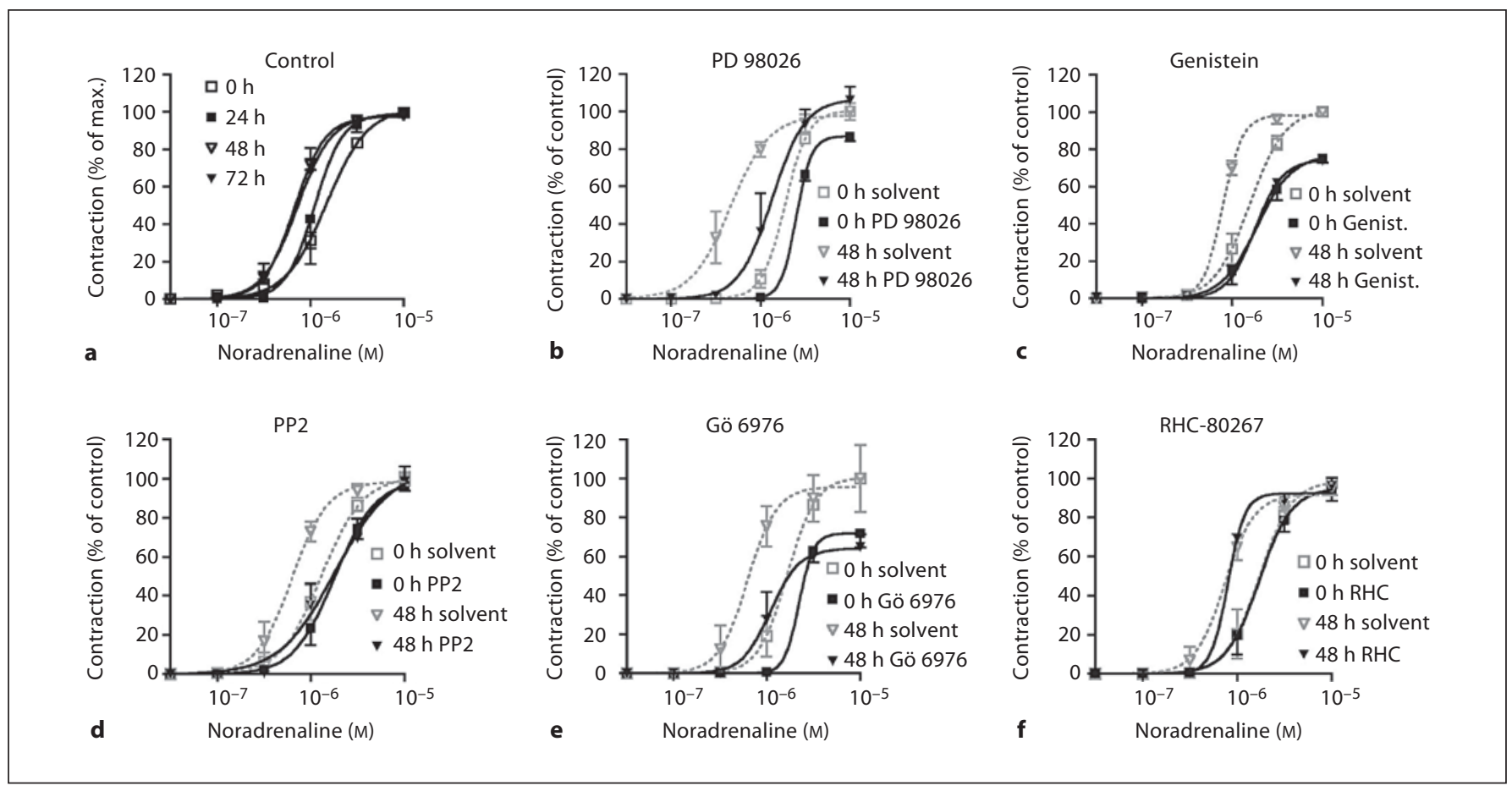

Fig. 1. Effect of src kinase, PKC, DAG lipase and MAPK inhibitors on the contractile response to noradrenaline in fresh and cultured mesenteric artery. a Control concentration-response curves to noradrenaline in freshly isolated arteries $(n=62)$ or in arteries cultured for $24 \mathrm{~h}(\mathrm{n}=6), 48 \mathrm{~h}(\mathrm{n}=62)$ or $72 \mathrm{~h}(\mathrm{n}=6)$. Data are expressed as percent of the maximum contraction. b-f Noradrenaline concentration-response curves in freshly isolated mesenteric arteries (squares) and in those cultured for $48 \mathrm{~h}$ (tri-

Table 2. Effect of organ culture on contractile responses of mesenteric resistance artery

Fresh artery $48 \mathrm{~h}$ cultured $(\mathrm{n}=62) \quad$ artery $(\mathrm{n}=62)$

\section{Noradrenaline}

Maximum contraction $(\mathrm{mN} / \mathrm{mm}) \quad 3.8 \pm 0.2 \quad 3.7 \pm 0.2$ $\mathrm{pD} 2$ $5.87 \pm 0.03 \quad 6.12 \pm 0.03^{\mathrm{a}}$

$\mathrm{KCl}$

Maximum contraction $(\mathrm{mN} / \mathrm{mm}) \quad 3.2 \pm 0.2 \quad 3.2 \pm 0.2$

Noradrenaline $\mathrm{pD} 2$ values were calculated by nonlinear regression of individual concentration-contraction curves. Each value represents the mean \pm SEM from $n$ determinations. Statistical analyses were performed with Student's t test.

${ }^{\mathrm{a}} \mathrm{p}<0.05$ vs. freshly isolated arteries. angles) determined after incubation with different antagonists (solid lines) or their solvent (dotted lines). b PD 98059 (10 $\mu \mathrm{mol} / \mathrm{l}$, fresh $\mathrm{n}=4$, cultured $\mathrm{n}=4)$. c Genistein $(1 \mu \mathrm{mol} / \mathrm{l}$, fresh $\mathrm{n}=8$, cultured $n=6)$. d PP2 $(1 \mu \mathrm{mol} / 1$, fresh $n=6$, cultured $n=8)$. e Gö $6976(10 \mu \mathrm{mol} / \mathrm{l}$, fresh $\mathrm{n}=4$, cultured $\mathrm{n}=4)$. f RHC-80267 (10 $\mu \mathrm{mol} / \mathrm{l}$, fresh $\mathrm{n}=4$, cultured $\mathrm{n}=4$ ). Data are expressed as percent of the maximum contraction evoked by noradrenaline before incubation with antagonists/solvents.

\section{Results}

\section{Cultured Arteries Are More Sensitive to \\ Noradrenaline than Are Freshly Isolated Mesenteric Arteries}

In freshly isolated mesenteric arteries mounted in a wire myograph, cumulative increase in the concentration of noradrenaline induced a concentration-dependent contraction. After 2 days of organ culture, we observed a significant increase in the sensitivity of the contraction to noradrenaline, which did not further change after 3 days of culture. At $48 \mathrm{~h}$ of culture, the concentration-response curve was shifted to the left, as indicated by the significant increase in the noradrenaline $\mathrm{pD} 2$ value, from $5.87 \pm 0.03(\mathrm{n}=62)$ in freshly isolated arteries to $6.12 \pm$ $0.03(\mathrm{n}=62)$ in cultured arteries $(\mathrm{p}<0.01$; fig. 1a, table 2$)$. Culturing the artery segments for $24 \mathrm{~h}$ did not evoke a significant change in the contractile response to noradrenaline ( $\mathrm{pD} 2$ was $5.89 \pm 0.14, \mathrm{n}=6)$. The maximum 
contraction evoked by $10 \mu \mathrm{mol} / \mathrm{l}$ noradrenaline was not affected by culture (table 2). Culture also did not change the contractile response to $100 \mathrm{mmol} / \mathrm{l} \mathrm{KCl}$ depolarizing solution (table 2).

\section{Noradrenaline-Evoked Contraction Requires}

Extracellular $\mathrm{Ca}^{2+}$ Entry in Both Fresh and Cultured

Mesenteric Arteries, but Cultured Arteries Are More

Sensitive to Blockers of TRPC Channels

The increase in cytosolic $\mathrm{Ca}^{2+}$ responsible for the noradrenaline-evoked contraction is known to originate from the intracellular and the extracellular compartments, through $\mathrm{Ca}^{2+}$ selective voltage-dependent channels (VOC) and non-selective cationic channels [8]. In order to investigate the contribution of $\mathrm{Ca}^{2+}$ entry to the contractile response to noradrenaline, we tested the effect of several inhibitors of $\mathrm{Ca}^{2+}$ channels in arteries mounted in the wire myograph.

To determine the involvement of VOC channels in noradrenaline-induced contraction, we used the dihydropyridine VOC inhibitor nimodipine. At $1 \mu \mathrm{mol} / \mathrm{l}$, nimodipine inhibited the contractile response of mesenteric arteries to $1 \mu \mathrm{mol} / \mathrm{l}$ noradrenaline by $94.6 \pm 0.1 \%(\mathrm{n}=$ 3 ), suggesting that VOC channels play a prominent role in the contraction (fig. 2). The effect of nimodipine was not affected by culture.

Recently, non-voltage-dependent cation channels belonging to the TRP family have been reported to be involved in artery contraction evoked by agonists [9]. To investigate their contribution to the $\mathrm{Ca}^{2+}$ entry pathways activated by noradrenaline and to the change evoked by artery culture, 3 blockers of non-voltage-dependent cation channels were used [10]. Lower concentrations of the inhibitors (flufenamic acid $10 \mu \mathrm{mol} / \mathrm{l}$, SKF-96365 $3 \mu \mathrm{mol} / \mathrm{l}$ and $\left.\mathrm{Gd}^{3+} 0.1 \mu \mathrm{mol} / \mathrm{l}\right)$ did not affect noradrenaline-evoked contraction in freshly isolated arteries but significantly displaced noradrenaline concentration-response curves in cultured arteries, indicating that cultured arteries were more sensitive to these compounds than freshly isolated arteries (fig. 3). Higher concentrations depressed noradrenaline contraction in fresh and in cultured arteries, but inhibition was more pronounced in cultured arteries.

The Increased Sensitivity to Noradrenaline in

Cultured Mesenteric Artery Is Abolished in the

Presence of src Kinase Inhibitors, but Is Unaffected by

PKC, Diacylglycerol Lipase and MAPK Inhibitors

$\mathrm{Ca}^{2+}$ entry evoked by $\alpha$-adrenergic agonists has been reported to result from the activation of TRPC6 by phos-

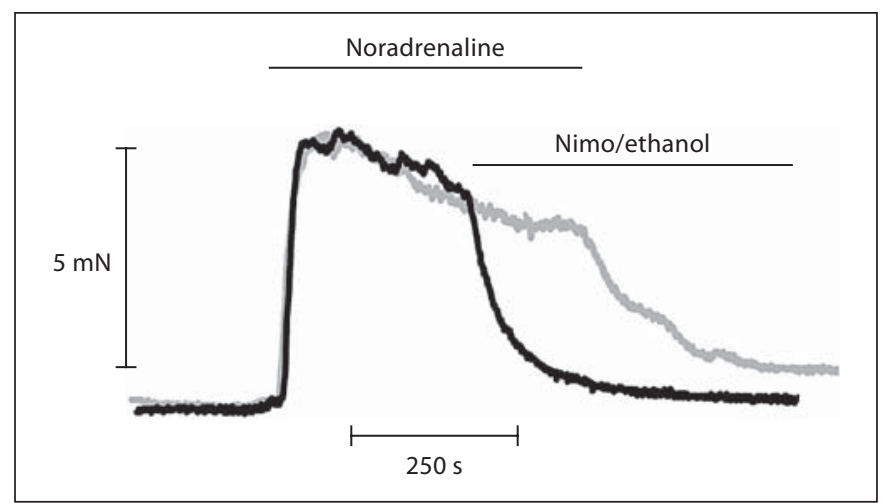

Fig. 2. Effect of nimodipine on contractile tension evoked by noradrenaline in mesenteric artery. Typical traces of the contraction induced by noradrenaline $(1 \mu \mathrm{mol} / \mathrm{l})$ in freshly isolated resistance mesenteric artery. Nimodipine (Nimo; $1 \mu \mathrm{mol} / \mathrm{l}$, black trace) or ethanol $(0.01 \%$, shaded trace) were added at the plateau of the contraction, as indicated. The experiment was repeated 3 times with the same result.

pholipase C-mediated generation of diacylglycerol (DAG) $[11,12]$. In contrast to reports showing the activation of $\mathrm{Ca}^{2+}$ entry by OAG, a synthetic analogue of DAG [13-16], we did not detect any contraction in response to OAG $(100 \mu \mathrm{mol} / \mathrm{l})$ in mesenteric arteries either before or after organ culture. To further test the potential involvement of DAG in the response to noradrenaline, we pre-treated vessels with the DAG lipase inhibitor RHC-80267 to prevent $D A G$ degradation. Pre-incubation of the mesenteric arteries with RHC-80267 did not affect the contraction evoked by noradrenaline either in cultured or in fresh arteries (fig. 1f, table 3).

The pre-incubation of the mesenteric arteries with the specific PKC inhibitor Gö $6976(10 \mu \mathrm{mol} / \mathrm{l})[16,17]$ depressed the contractile response to noradrenaline. The maximum response was decreased by $20.9 \pm 8.9 \%(\mathrm{n}=$ 4) and $35 \pm 6.3 \%(n=4)$, in fresh and cultured mesenteric arteries, respectively. However, Gö 6976 did not affect the increase in noradrenaline sensitivity observed in cultured arteries compared to fresh tissue (fig. 1e, table 3). A similar effect was observed with another PKC inhibitor, GF-109203 (table 3).

Src kinases are highly expressed in smooth muscle cells and have been suggested to play a role in the regulation of arteriolar contractility [18]. In order to investigate their potential role in the change in noradrenaline-evoked contraction in cultured mesenteric artery, we used the src kinase family inhibitors genistein and PP2. Genistein $(1 \mu \mathrm{mol} / \mathrm{l})$ displaced the noradrenaline concentration-response curve to the right, and depressed the maximum 
Fig. 3. Effect of cation channel inhibitors on noradrenaline-induced contraction. Freshly isolated mesenteric arteries $(\mathbf{a}, \mathbf{c}, \mathbf{e})$ and those cultured for $48 \mathrm{~h} \mathrm{(b,} \mathrm{d,} \mathrm{f)} \mathrm{were}$ stimulated by cumulative concentrations of noradrenaline in the absence or in the presence of SKF 96365 (a, b), flufenamic acid (FFA; c, d), or $\mathrm{Gd}^{3+}(\mathbf{e}, \mathbf{f})$, or their solvent. Data are expressed as percent of the maximum contraction evoked by noradrenaline in the absence of antagonist/ solvent and are shown as means \pm SEM $(\mathrm{n}=4) .{ }^{*} \mathrm{p}<0.05$ versus curves measured in the presence of the solvent (ANOVA).
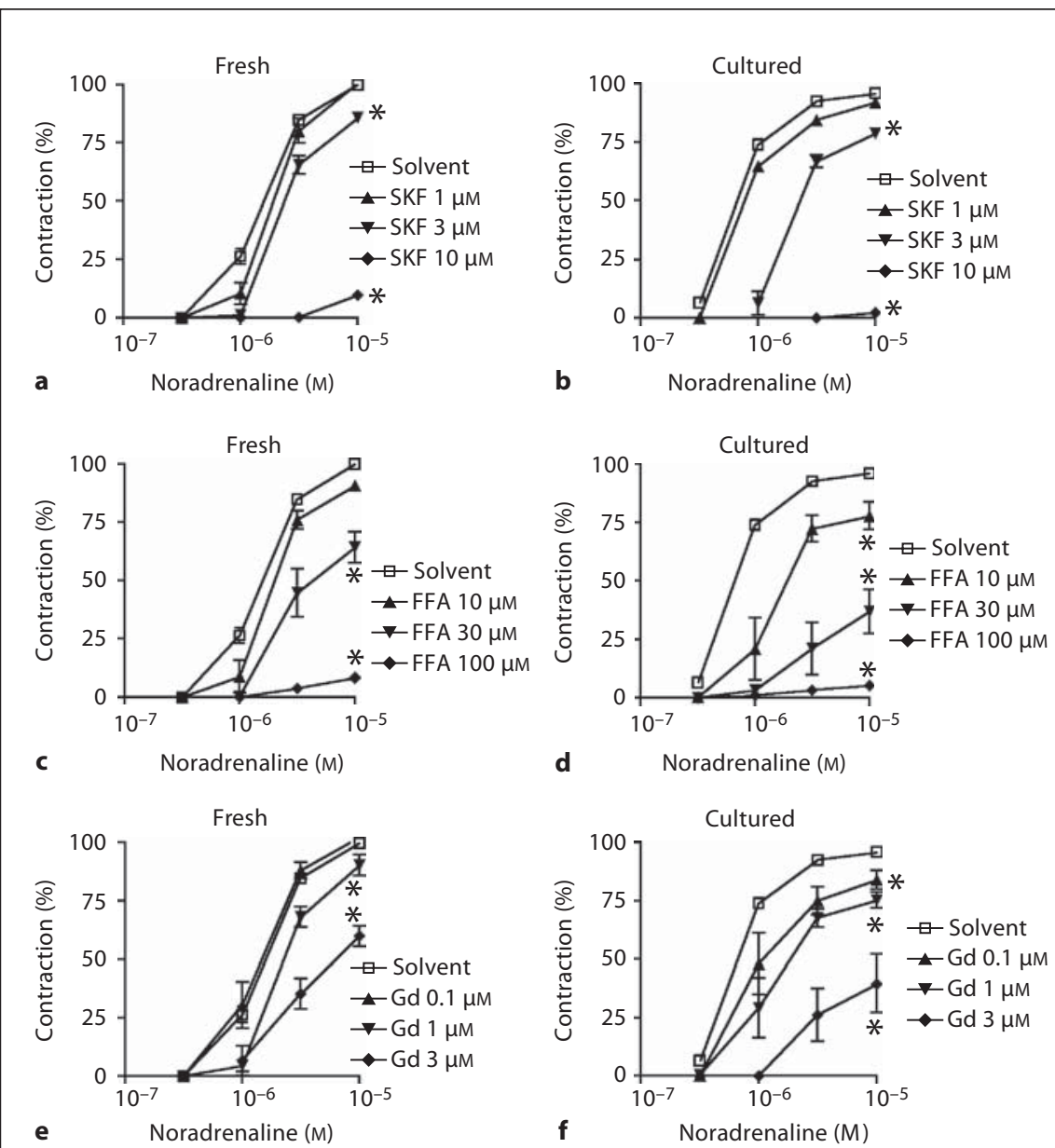

Table 3. Effect of antagonists on noradrenaline $\mathrm{pD} 2$ value in fresh and cultured mesenteric arteries

\begin{tabular}{llllll}
\hline Antagonists & \multicolumn{2}{l}{ Fresh artery } & & \multicolumn{2}{l}{48 h cultured artery } \\
\cline { 2 - 3 } & \multicolumn{1}{ll}{ solvent } & with antagonist & & solvent & with antagonist \\
\hline PP2 $(1 \mu \mathrm{mol} / \mathrm{l})$ & $5.9 \pm 0.09(\mathrm{n}=8)$ & $5.71 \pm 0.09(\mathrm{n}=6)$ & & $6.10 \pm 0.02^{\mathrm{a}}(\mathrm{n}=8)$ & $5.81 \pm 0.12(\mathrm{n}=8)$ \\
Genistein $(1 \mu \mathrm{mol} / \mathrm{l})$ & $5.83 \pm 0.10(\mathrm{n}=6)$ & $5.71 \pm 0.21(\mathrm{n}=8)$ & & $6.23 \pm 0.09^{\mathrm{a}}(\mathrm{n}=7)$ & $5.78 \pm 0.10(\mathrm{n}=6)$ \\
PD 98059 $(10 \mu \mathrm{mol} / \mathrm{l})$ & $5.75 \pm 0.04(\mathrm{n}=5)$ & $5.64 \pm 0.05(\mathrm{n}=4)$ & & $6.26 \pm 0.11^{\mathrm{a}}(\mathrm{n}=4)$ & $5.89 \pm 0.07^{\mathrm{b}}(\mathrm{n}=5)$ \\
Gö 6976 $(10 \mu \mathrm{mol} / \mathrm{l})$ & $5.78 \pm 0.08(\mathrm{n}=4)$ & $5.64 \pm 0.10(\mathrm{n}=4)$ & & $6.19 \pm 0.06^{\mathrm{a}}(\mathrm{n}=4)$ & $6.95 \pm 0.04^{\mathrm{b}}(\mathrm{n}=4)$ \\
GF109203 $(10 \mu \mathrm{mol} / \mathrm{l})$ & $5.76 \pm 0.03(\mathrm{n}=4)$ & $5.10 \pm 0.05^{\mathrm{a}}(\mathrm{n}=4)$ & & $6.29 \pm 0.06^{\mathrm{a}}(\mathrm{n}=4)$ & $5.46 \pm 0.08^{\mathrm{b}}(\mathrm{n}=4)$ \\
RHC-80267 $(10 \mu \mathrm{mol} / \mathrm{l})$ & $5.77 \pm 0.05(\mathrm{n}=7)$ & $5.78 \pm 0.09(\mathrm{n}=4)$ & & $6.13 \pm 0.14^{\mathrm{a}}(\mathrm{n}=5)$ & $6.09 \pm 0.01^{\mathrm{b}}(\mathrm{n}=4)$
\end{tabular}

$\mathrm{pD} 2$ values were calculated by nonlinear regression of individual experimental data. Each value represents the mean \pm SEM from $\mathrm{n}$ determinations. Statistical analyses were performed with ANOVA.

${ }^{\mathrm{a}} \mathrm{p}<0.05$ vs. untreated fresh arteries; ${ }^{\mathrm{b}} \mathrm{p}<0.05 \mathrm{vs}$. fresh arteries incubated in the presence of the same antagonist. 
Fig. 4. $\mathrm{Ca}^{2+}$ signal and contraction evoked by noradrenaline were increased in cultured mesenteric artery, while $\mathrm{KCl}$-induced responses were not affected. a $\mathrm{Ca}^{2+}$ signal (upper panel) and simultaneous contraction (lower panel) evoked by cumulative concentrations of noradrenaline in fresh (open squares) and cultured (closed triangles) mesenteric arteries. Data (means \pm SEM from 5 determinations) are expressed as percent of the responses to $\mathrm{KCl}$ in the same artery segment. ${ }^{*} \mathrm{p}<$ 0.05 (ANOVA). b Increase in $\mathrm{Ca}^{2+}$ signal (upper panel) and simultaneous contraction (lower panel) evoked by $100 \mathrm{mmol} / \mathrm{l}$ $\mathrm{KCl}$ solution in the same segments of fresh and cultured mesenteric artery. Data are means \pm SEM from 5 determinations. ${ }^{*} \mathrm{p}<0.05$ versus freshly isolated arteries (t test).

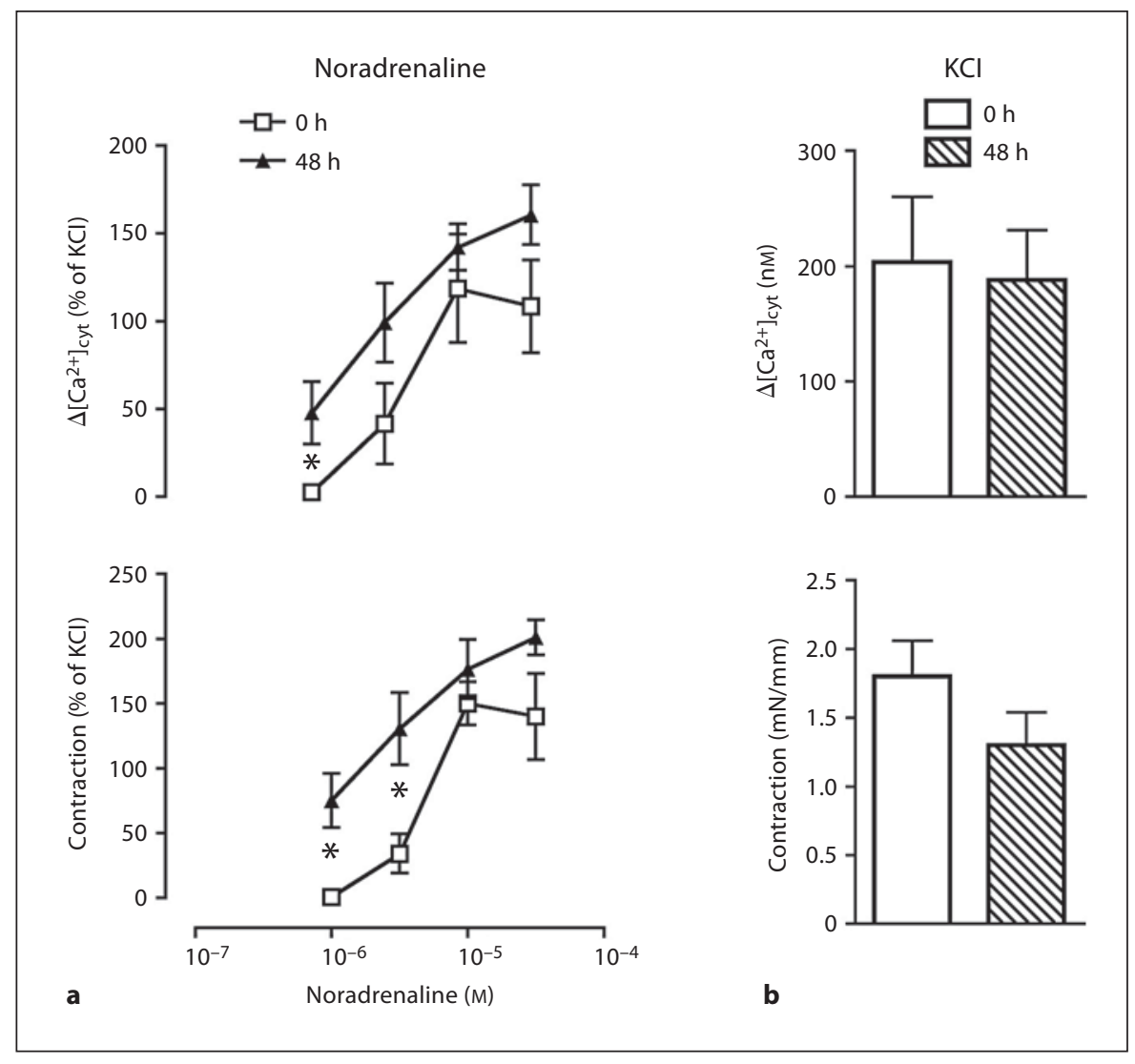

response. It was more potent in cultured arteries than in freshly isolated ones so that in the presence of genistein the difference between fresh and cultured arteries was abolished (fig. 1c, table 3). The same effect was observed when arteries were incubated with PP2 $(1 \mu \mathrm{mol} / \mathrm{l})$, a more specific inhibitor of src kinases [13]. PP2 did not affect the contraction to noradrenaline in freshly isolated arteries but displaced the concentration-response curve to noradrenaline to the right in cultured arteries so that, in the presence of PP2, noradrenaline concentration response curves in fresh and cultured arteries were superimposed (fig. 1d, table 3). PP2 did not affect the maximum contraction to noradrenaline (fig. 1d).

Phosphorylation of ERK1/2 has been reported to be required for mesenteric artery contraction to ET-1 [19]. Moreover, the presence of MAPK inhibitors in the culture medium of mesenteric artery prevents the increase in artery contraction to noradrenaline [5]. In order to test the involvement of MAPK in the contraction evoked by noradrenaline, we measured the response of the arteries to noradrenaline in the presence of the MAPK inhibitor PD $98059(10 \mu \mathrm{mol} / \mathrm{l})$. Figure $1 \mathrm{~b}$ shows that noradrena- line-evoked contraction was depressed in both cultured and freshly isolated mesenteric arteries. However, PD 98059 did not affect the increase in sensitivity to noradrenaline observed in cultured arteries compared to freshly isolated arteries (fig. 1b, table 3).

\section{Organ Culture Increases the Sensitivity of $\mathrm{Ca}^{2+}$ Signal to Noradrenaline}

Fura-2 fluorescence measurement showed that the increase in contractile tension evoked by noradrenaline was associated with a parallel increase in cytosolic $\mathrm{Ca}^{2+}$ (fig. 4). Measurement of cytosolic $\mathrm{Ca}^{2+}$ in freshly isolated and cultured arteries showed that culture similarly increased the sensitivity of the $\mathrm{Ca}^{2+}$ signal and the contraction to noradrenaline (fig. 4), without affecting the resting cytosolic $\mathrm{Ca}^{2+}$ concentration, which was estimated to be $143 \pm 12 \mathrm{nmol} / \mathrm{l} \mathrm{Ca}{ }^{2+}(\mathrm{n}=15)$ and $120 \pm 10 \mathrm{nmol} / \mathrm{l}$ $\mathrm{Ca}^{2+}(\mathrm{n}=17)$, in freshly isolated and cultured mesenteric artery segments, respectively. In fura-2 loaded arteries, the increase in cytosolic $\mathrm{Ca}^{2+}$ and the contraction evoked by $100 \mathrm{mmol} / \mathrm{l} \mathrm{KCl}$ solution in freshly isolated and in cultured arteries were not statistically different (fig. 4). 
Fig. 5. The increased $\mathrm{Ca}^{2+}$ release evoked by noradrenaline in cultured mesenteric arteries was normalised in the presence of the src kinase inhibitor, PP2. The left panels show typical traces of $\mathrm{Ca}^{2+}$ signal (upper traces) and contraction (lower traces) evoked by noradrenaline $(3 \mu \mathrm{mol} / \mathrm{l})$ in resistance mesenteric artery perfused with $\mathrm{Ca}^{2+}$-free solution and after re-addition of $\mathrm{Ca}^{2+}$ to the solution. The right panels show mean values of the increase in $\mathrm{Ca}^{2+}$ signal (upper graphs) and contraction (lower graphs) induced by noradrenaline (3 $\mu \mathrm{mol} / \mathrm{l})$ in the absence and presence of external $\mathrm{Ca}^{2+}$ ( $\mathrm{n}=6$ artery segments) in control artery and in the presence of the src kinase inhibitor PP2 (1 $\mu \mathrm{mol} / \mathrm{l})$. Data are expressed as percentage of the responses evoked by $\mathrm{KCl}$ in the same artery segment. ${ }^{\mathrm{a}} \mathrm{p}<0.05$ versus untreated artery; ${ }^{\mathrm{b}} \mathrm{p}<$ 0.05 versus freshly isolated arteries (ANOVA). a Freshly isolated mesenteric artery. b Cultured mesenteric artery.

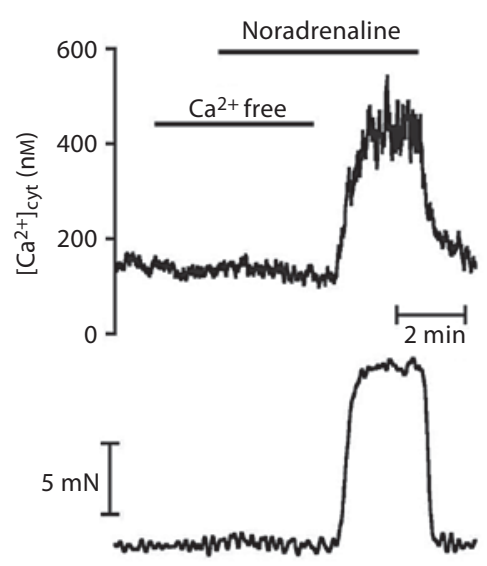

a
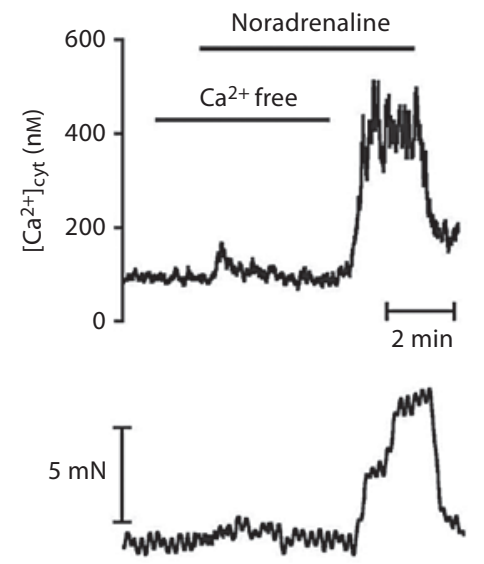

b
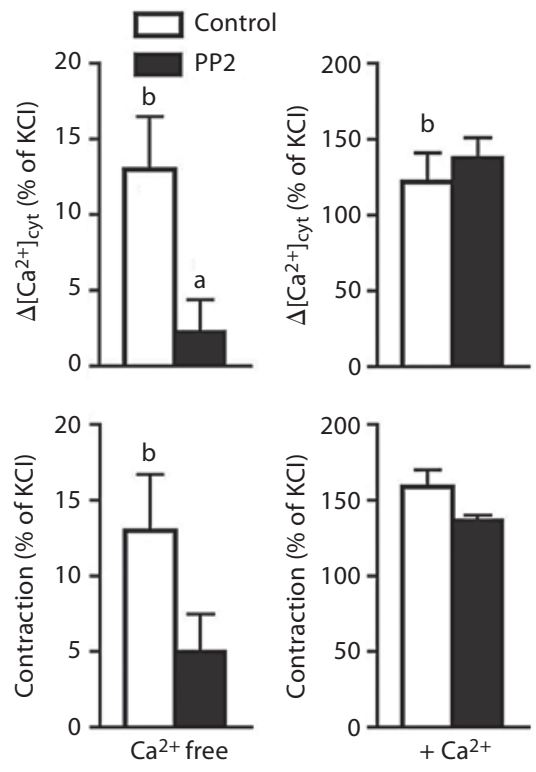

\section{Src Kinase Is Involved in the Increased $\mathrm{Ca}^{2+}$ Signal}

Evoked by Noradrenaline in Cultured Arteries

To further dissect the vascular response to noradrenaline after organ culture, we studied the effect of noradrenaline in the absence and presence of $\mathrm{Ca}^{2+}$ in the external solution. In the absence of $\mathrm{Ca}^{2+}$, an increase in $\mathrm{Ca}^{2+}$ signal and contractile tension in response to noradrenaline were hardly detected in freshly isolated mesenteric arteries $\left(6.3 \pm 4.1 \mathrm{nmol} / 1 \mathrm{Ca}^{2+}, \mathrm{n}=7\right)$. However, after $48 \mathrm{~h}$ of organ culture, noradrenaline produced a sig- nificant increase in $\mathrm{Ca}^{2+}$ signal in arteries bathed in the absence of $\mathrm{Ca}^{2+}\left(39 \pm 11 \mathrm{nmol} / \mathrm{l} \mathrm{Ca}{ }^{2+}, \mathrm{n}=7, \mathrm{p}<0.05\right.$ compared to freshly isolated artery segments) accompanied by a small increase in contractile tension $(0.6 \pm 0.1$ $\mathrm{mN} / \mathrm{mm}$ compared to $0.2 \pm 0.1 \mathrm{mN} / \mathrm{mm}$ in freshly isolated arteries; fig. 5b). The $\mathrm{Ca}^{2+}$ release evoked by noradrenaline in cultured arteries in $\mathrm{Ca}^{2+}$-free solution was significantly inhibited by PP2 $\left(10 \pm 6 \mathrm{nmol} / \mathrm{l} \mathrm{Ca}^{2+}, \mathrm{n}=\right.$ $4, p<0.05$ vs. control), suggesting the involvement of src kinase in this response. PP2 also inhibited the contrac- 


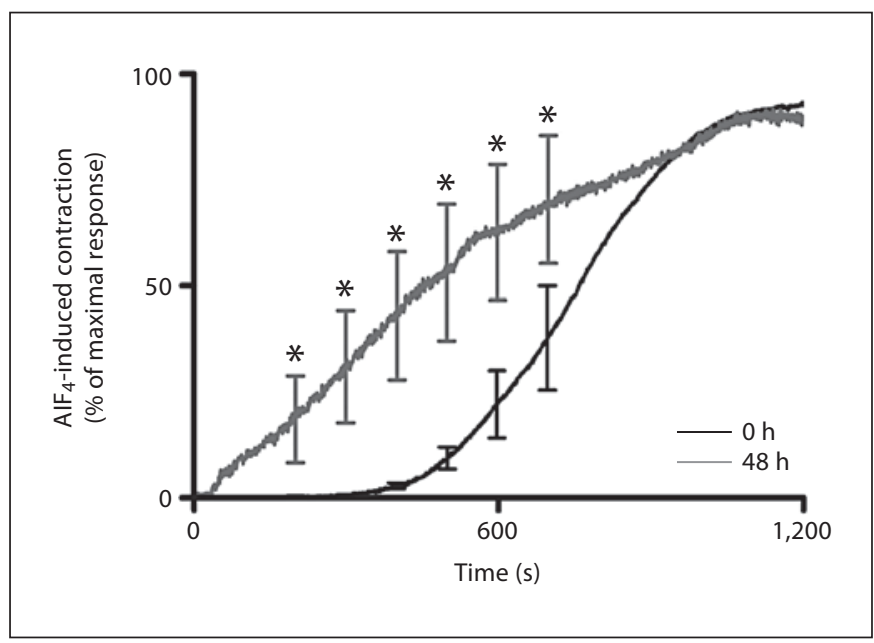

Fig. 6. Contractile response evoked by $\mathrm{AlF}_{4}$ in fresh (black line) and cultured (shaded line) mesenteric arteries. Results are expressed as percentage of maximum contraction evoked by 10 $\mu \mathrm{mol} / \mathrm{l} \mathrm{AlF}_{4}$ in fresh and cultured arteries. Traces are mean values from 7 experiments. Vertical bars represent SEM values, shown at selected time points. ${ }^{*} \mathrm{p}<0.05$ between the contractile responses of fresh and cultured arteries (ANOVA).

tion evoked by noradrenaline in $\mathrm{Ca}^{2+}$-free solution, but this effect did not reach a statistically significant level.

After the addition of $\mathrm{Ca}^{2+}$ to the physiological solution in the continuous presence of noradrenaline, $\mathrm{Ca}^{2+}$ signal and contraction rapidly increased in fresh and in cultured arteries, reflecting the activation of $\mathrm{Ca}^{2+}$ entry. The increase in $\mathrm{Ca}^{2+}$ signal was larger in cultured arteries compared to freshly isolated tissue $(312 \pm 98 \mathrm{nmol} / \mathrm{l}$ $\mathrm{Ca}^{2+}, \mathrm{n}=6$, vs. $260 \pm 29 \mathrm{nmol} / \mathrm{l} \mathrm{Ca}^{2+}, \mathrm{n}=6$, respectively; fig. 5). These responses to noradrenaline were not significantly affected by PP2, either in freshly isolated or in cultured mesenteric arteries (fig. 5b).

\section{Contraction of Cultured Mesenteric Arteries Is More}

Sensitive to $\mathrm{AlF}_{4}$

We used $\mathrm{AlF}_{4}(10 \mu \mathrm{mol} / \mathrm{l})$, a potent activator of G-proteins, in order to bypass receptor activation and find out whether the sensitization of contractile response after organ culture was related to a change at the level of the adrenergic receptor. $\mathrm{AlF}_{4}$ induced a slowly developing tonic contraction in fresh mesenteric arteries. In cultured mesenteric arteries, the contractile response evoked by $\mathrm{AlF}_{4}$ developed more rapidly than in fresh arteries (time to reach $50 \%$ of maximal contraction was $431 \pm 128 \mathrm{~s}$ and $768 \pm 51 \mathrm{~s}$ for fresh and cultured mesenteric arteries, respectively, $\mathrm{p}<0.05$; fig. 6 ). The maximum contractions
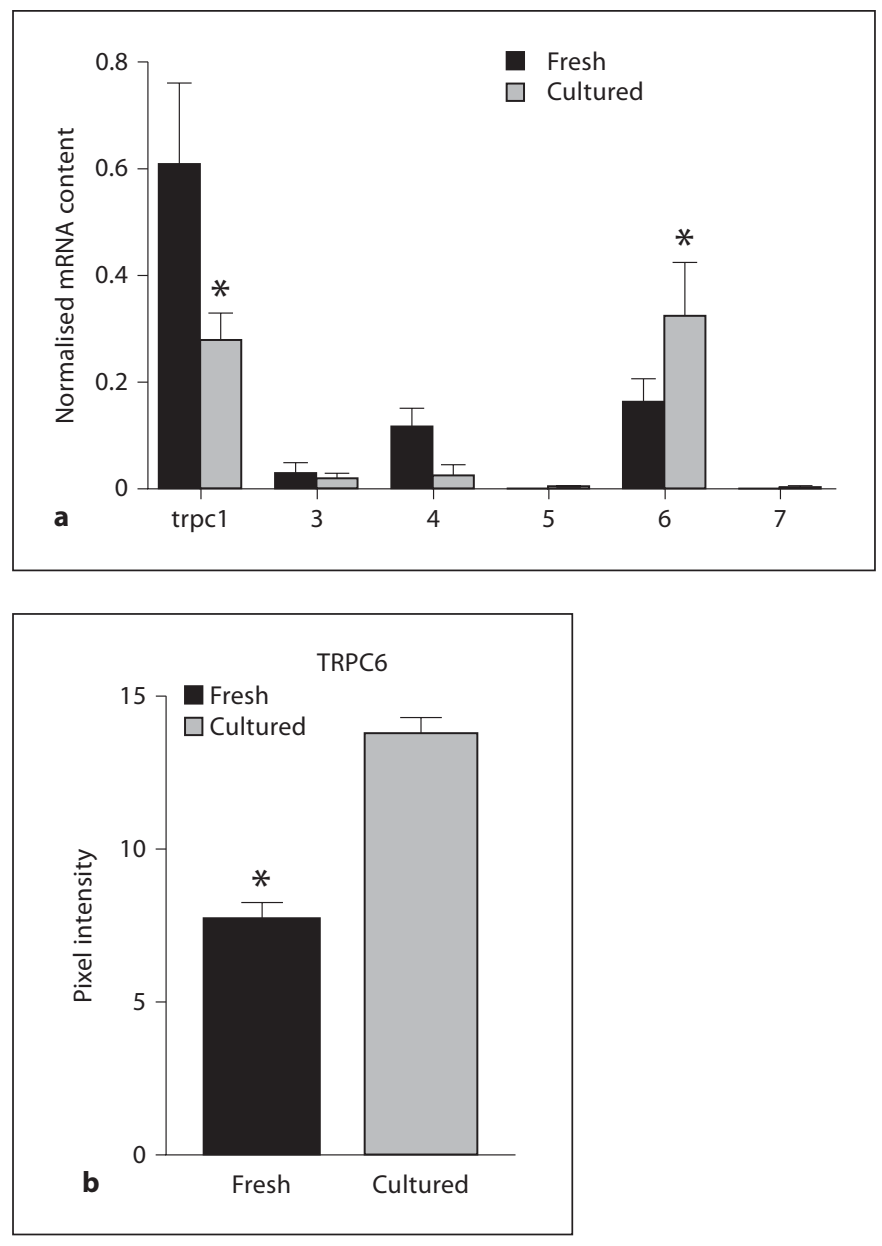

Fig. 7. TRPC expression in fresh and cultured rat mesenteric arteries. a mRNA expression of trpc1 and trpc3-7. The mRNA levels were adjusted to rpl32 expression. Data are means \pm SEM from 5 independent experiments. b Immunofluorescence detection of TRPC6 protein expression in fresh and cultured mesenteric arteries. 10 scan images were analyzed in each artery and the results are expressed as means \pm SEM of 5 different arteries. ${ }^{*} \mathrm{p}<0.05$ between freshly isolated and cultured artery ( $\mathrm{t}$ test).

evoked by $\mathrm{AlF}_{4}$ were not significantly different between fresh and cultured arteries $(3.33 \pm 0.58$ and $3.08 \pm 0.37$ $\mathrm{mN} / \mathrm{mm}, \mathrm{n}=7$, respectively).

\section{Up-Regulation of TRPC6 Expression after Organ \\ Culture}

We investigated the expression of TRPC in mesenteric arteries before and after organ culture. RT-PCR performed with mesenteric artery mRNA showed the expression of trpc 1 and 3-7 isoforms in fresh and cultured mesenteric artery. $\operatorname{trpc} 1$ and 6 were the most abundant 
isoforms in freshly isolated arteries, trpc 4 was expressed at an intermediate level and trpc5 and 7 mRNAs were practically undetectable (fig. 7a). In arteries cultured for 2 days, trpcl mRNA expression decreased by $47 \pm 8 \%$ $(\mathrm{n}=5, \mathrm{p}<0.05)$, while trpc6 mRNA expression increased by $92 \pm 24 \%(\mathrm{n}=5, \mathrm{p}<0.05)$ in comparison with noncultured arteries. The protein expression of TRPC6 was investigated by confocal microscopy in whole mounts of fresh and cultured mesenteric arteries using anti-TRPC6 antibodies. Average pixel fluorescence was significantly higher in cultured artery segments compared to freshly isolated arteries (13.8 $\pm 0.54, \mathrm{n}=5$ artery segments, vs. $7.7 \pm 0.52, \mathrm{n}=5$ artery segments, in cultured and fresh mesenteric arteries, respectively; fig. $7 \mathrm{~b}$ ).

\section{Discussion}

The present results show that cultured arteries exhibit an increased sensitivity to noradrenaline, as indicated by a significant shift to the left of the noradrenaline concentration-contraction curve in comparison with noncultured mesenteric arteries. This sensitization was completely inhibited by 2 different src kinase inhibitors.

Noradrenaline-evoked contraction is associated with the release of intracellular $\mathrm{Ca}^{2+}$ and the entry of $\mathrm{Ca}^{2+}$ from the extracellular compartment. These 2 components in the response to noradrenaline were identified by perfusing the artery with $\mathrm{Ca}^{2+}$-free and $\mathrm{Ca}^{2+}$-containing solutions. Activation of intracellular $\mathrm{Ca}^{2+}$ release and contraction by noradrenaline in the absence of external $\mathrm{Ca}^{2+}$ were hardly detected in freshly isolated mesenteric arteries. The addition of $\mathrm{Ca}^{2+}$ to the perfusion solution produced a rapid increase in cytosolic $\mathrm{Ca}^{2+}$ and in contraction. The $\mathrm{Ca}^{2+}$ signal evoked by the addition of $\mathrm{Ca}^{2+}$ to the perfusion solution was completely inhibited by nimodipine (data not shown), which also completely inhibited the contraction evoked by noradrenaline. This observation indicates that $\mathrm{Ca}^{2+}$ entry through VOC plays a prominent role in the contractile response of mesenteric artery to noradrenaline.

Culture of mesenteric artery for $48 \mathrm{~h}$ in the absence of serum resulted in a significant increase in the sensitivity of contraction to noradrenaline, without change in the maximal amplitude of the contraction. The increase in contraction was associated with an increase in $\mathrm{Ca}^{2+}$ signal both in the absence of $\mathrm{Ca}^{2+}$ and after addition of $\mathrm{Ca}^{2+}$ in the solution. The increase in intracellular $\mathrm{Ca}^{2+}$ release and in capacitative $\mathrm{Ca}^{2+}$ entry has been reported in rat basilar and tail arteries after 3-4 days in culture [20]. In- terestingly, we found that, in cultured arteries, src family tyrosine kinase inhibitor PP2 and the less selective tyrosine kinase inhibitor genistein abolished the increased sensitivity of mesenteric artery contraction to noradrenaline. In fura-2-loaded cultured mesenteric arteries, PP2 completely abolished noradrenaline-induced $\mathrm{Ca}^{2+}$ release measured in artery perfused with $\mathrm{Ca}^{2+}$-free solution, whereas it did not affect $\mathrm{Ca}^{2+}$ entry.

Src kinases form a family of widely expressed non-receptor tyrosine kinases. Among the numerous src-related kinases, c-src has been reported to be highly expressed in VSMCs. It has been implicated in the regulation of vascular smooth muscle tone $[21,22]$, and has been reported to modulate L-type $\mathrm{Ca}^{2+}$ channel activity $[23,24]$, and to regulate TRPC6 channel activity by direct phosphorylation [13].

The present results indicate that the increased $\mathrm{Ca}^{2+}$ entry evoked by noradrenaline in cultured arteries was not affected by PP2. This observation is not consistent with the involvement of src kinases in the activation of $\mathrm{Ca}^{2+}$ entry, either through L-type $\mathrm{Ca}^{2+}$ channels or TRPC6 channels [11]. It implies that the kinases might regulate $\mathrm{SR} \mathrm{Ca}^{2+}$ content or permeability. This result is in line with the reported inhibition of agonist-evoked $\mathrm{Ca}^{2+}$ release by src tyrosine kinase inhibitors in several cell types, which has led to the suggestion that tyrosine phosphorylation of the $\mathrm{Gq} / 11$ subunit by tyrosine kinases contributes to receptor-mediated activation of Gq [25]. PP2 and phospholipase $\mathrm{C}$ inhibition have also been reported to abolish the $\mathrm{Ca}^{2+}$ oscillations induced by OAG in various cell types in $\mathrm{Ca}^{2+}$-free solution, suggesting that src kinases are required for the stimulation of phospholipase $\mathrm{C}$ activity by OAG [26]. Src tyrosine kinases also activate phospholipase $C \gamma 2$ [27] and regulate the levels of phospholipids [28].

At the light of these reports, we may suggest that the activation of phospholipase $\mathrm{C}$ by src kinase may contribute to the increased $\mathrm{Ca}^{2+}$ release evoked by noradrenaline in cultured artery. However, we did not detect any effect of OAG on the contractile tension of freshly isolated and cultured mesenteric arteries, what suggests that DAG is not involved in the increased reactivity to noradrenaline in cultured artery.

Artery culture was also associated with an increase in the $\mathrm{Ca}^{2+}$ entry evoked by noradrenaline. The importance of $\mathrm{Ca}^{2+}$ entry for the contractile response to noradrenaline in resistance mesenteric artery was confirmed by the inhibition of contraction by the voltage-dependent $\mathrm{Ca}^{2+}$ channel inhibitor nimodipine, which indicated that most of the $\mathrm{Ca}^{2+}$ entry occurs through VOC. Noradrenaline- 
evoked contraction was abolished not only by nimodipine, but also by flufenamic acid or SKF-96365, known to modulate agonist-evoked $\mathrm{Ca}^{2+}$ entry in several cell types, through their interaction with TRPC channels $[29,30]$. This is compatible with the hypothesis that non-selective cation channels could mediate cell membrane depolarization leading to the opening of VOC. In portal vein, Inoue et al. [11] reported, using an antisense strategy, that TRPC6, which is highly expressed, is an important component of $\alpha$-adrenoceptor signalling pathway. The activity of the TRPC6 channel has been reported to be increased by flufenamic acid [11], which also inhibits other TRPC channel proteins $[31,32]$. The inhibitory effect of flufenamic acid on noradrenaline contraction in mesenteric artery thus suggests that heterotetrameric TRPC channels might be involved in the contractile response to noradrenaline, in agreement with PCR data indicating that most TRPC isoforms are expressed in this tissue.

Interestingly, the increased contractile response to noradrenaline was more sensitive to cation channel inhibitors in cultured arteries than in freshly isolated artery segments, suggesting that the contribution of non-selective cation channels in the response to noradrenaline is higher after culture. This observation may be related to the up-regulation of TRPC6 expression in cultured arteries compared to freshly isolated arteries. Changes in TRPC expression with organ culture have been reported by Bergdahl et al. [1] in cerebral arteries, where culture was associated with increased expression of TRPC6 and of TRPC1. However, we did not confirm the increased expression of trpcl in mesenteric artery after organ culture [1]. This discrepancy might be due to vessel difference (mesenteric vs. cerebral) or the different culture conditions. Whether increased expression of TRPC6 is responsible for the potentiation of noradrenaline responses after culture cannot be definitively determined from the present data. In the absence of a selective pharmacologic inhibitor, inhibition of protein expression will be required to address this question. Alternatively, altered membrane potential regulation, or a change in the signalling pathway activated by noradrenaline might contribute to the increased $\mathrm{Ca}^{2+}$ entry evoked by noradrenaline in cultured arteries.

Increased contraction of cultured rat mesenteric artery in response to noradrenaline has been ascribed to the up-regulation of $\alpha 1$-adrenoreceptor [5]. Although a change in the expression of adrenergic receptor with organ culture cannot be ruled out, it cannot explain all the observations reported in the present study, and in particular, the selective inhibition of noradrenaline-evoked responses by PP2. Moreover, the contraction evoked by several other agonists (unpubl. data) and by $\mathrm{AlF}_{4}$, which directly activates $G$ protein [33-35], were also enhanced after organ culture, in comparison with freshly isolated arteries. Nevertheless, a change in the distribution of receptor sub-types or in the localisation of the receptors might occur with culture. Further study should test this possibility.

The present data indicate that the increased reactivity to noradrenaline observed after organ culture of resistance mesenteric artery is associated with increase in $\mathrm{Ca}^{2+}$ entry through non-selective calcium channel and with increased $\mathrm{Ca}^{2+}$ release, which involves src family kinase. Increased vascular reactivity is reported in several vascular diseases like hypertension [36] or atherosclerosis [37]. Enhanced TRPC6 expression and ROC currents have been described in VSMCs from DOCA-salt hypertensive rats, and is proposed to contribute to altered vascular reactivity and to hypertension [38]. On the other hand, src has been reported to be involved in the cellular growth response to pressure stimulus [39], and to mediate VSMC growth in response to angiotensin [40]. The present results thus suggest that organ culture may reproduce vascular alterations characterising hypertension.

\section{Acknowledgements}

This work was supported by a grant from the Ministère de l'Education et de la Recherche Scientifique (Action Concertée No. 06/11-339) and from the FRSM (grant No. 3.4601.06).

References
1 Bergdahl A, Gomez MF, Wihlborg AK, Erlinge D, Eyjolfson A, Xu SZ, Beech DJ, Dreja K, Hellstrand P: Plasticity of TRPC expression in arterial smooth muscle: correlation with store-operated $\mathrm{Ca}^{2+}$ entry. Am J Physiol Cell Physiol 2005;288:C872-C880.

2 Guibert C, Savineau JP, Crevel H, Marthan $\mathrm{R}$, Rousseau E: Effect of short-term organoid culture on the pharmaco-mechanical properties of rat extra- and intrapulmonary arteries. Br J Pharmacol 2005;146:692-701.

- 3 Hill BJ, Katwa LC, Wamhoff BR, Sturek M: Enhanced endothelin(A) receptor-mediated calcium mobilization and contraction in organ cultured porcine coronary arteries. J Pharmacol Exp Ther 2000;295:484-491.

4 Jamali R, Edvinsson L: Involvement of protein kinases on the upregulation of endothelin receptors in rat basilar and mesenteric arteries. Exp Biol Med (Maywood) 2006;231: 403-411. 
$\checkmark 5$ Cao YX, Xu CB, Luo GG, Edvinsson L: Upregulation of alpha $1_{\mathrm{A}}$-adrenoceptors in rat mesenteric artery involves intracellular signal pathways. Basic Clin Pharmacol Toxicol 2006;98:61-67.

6 Ghisdal P, Gomez JP, Morel N: Action of a NO donor on the excitation-contraction pathway activated by noradrenaline in rat superior mesenteric artery. J Physiol 2000; 522:83-96.

$\checkmark 7$ Ghisdal P, Vandenberg G, Morel N: Rho-dependent kinase is involved in agonist-activated calcium entry in rat arteries. J Physiol 2003;551:855-867.

$\checkmark 8$ McFadzean I, Gibson A: The developing relationship between receptor-operated and store-operated calcium channels in smooth muscle. Br J Pharmacol 2002;135:1-13.

$\checkmark 9$ Reading SA, Earley S, Waldron BJ, Welsh DG, Brayden JE: TRPC3 mediates pyrimidine receptor-induced depolarization of cerebral arteries. Am J Physiol Heart Circ Physiol 2005;288:H2055-H2061.

$\checkmark 10$ Alexander SPH, Mathie A, Peters JA: Guide to receptors and channels (GRAC), 3rd ed. Br J Pharmacol 2008;153(suppl 2):S1-S209.

-11 Inoue R, Okada T, Onoue H, Hara Y, Shimizu S, Naitoh S, Ito Y, Mori Y: The transient receptor potential protein homologue TRP6 is the essential component of vascular alpha(1)-adrenoceptor-activated $\mathrm{Ca}(2+)$-permeable cation channel. Circ Res 2001;88: 325-332.

-12 Hofmann T, Obukhov AG, Schaefer M, Harteneck C, Gudermann T, Schultz G: Direct activation of human TRPC6 and TRPC3 channels by diacylglycerol. Nature 1999;397: 259-263.

-13 Hisatsune C, Kuroda Y, Nakamura K, Inoue T, Nakamura T, Michikawa T, Mizutani A, Mikoshiba K: Regulation of TRPC6 channel activity by tyrosine phosphorylation. J Biol Chem 2004;279:18887-18894.

-14 Hichami A, Morin C, Rousseau E, Khan NA: Diacylglycerol-containing docosahexaenoic acid in acyl chain modulates airway smooth muscle tone. Am J Respir Cell Mol Biol 2005; 33:378-386.

-15 Aires V, Hichami A, Boulay G, Khan NA: Activation of TRPC6 calcium channels by diacylglycerol (DAG)-containing arachidonic acid: a comparative study with DAG-containing docosahexaenoic acid. Biochimie 2007;89:926-937.

-16 Martiny-Baron G, Kazanietz MG, Mischak H, Blumberg PM, Kochs G, Hug H, Marme $\mathrm{D}$, Schachtele C: Selective inhibition of protein kinase $\mathrm{C}$ isozymes by the indolocarbazole Go 6976. J Biol Chem 1993;268:91949197.

- 17 Eto M, Kitazawa T, Yazawa M, Mukai H, Ono Y, Brautigan DL: Histamine-induced vasoconstriction involves phosphorylation of a specific inhibitor protein for myosin phosphatase by protein kinase $\mathrm{C}$ alpha and delta isoforms. J Biol Chem 2001;276:2907229078.
18 Che Q, Carmines PK: Src family kinase involvement in rat preglomerular microvascular contractile and $\left[\mathrm{Ca}^{2+}\right]$ i responses to ANG II. Am J Physiol Renal Physiol 2005;288: F658-F664.

19 Luo G, Jamali R, Cao YX, Edvinsson L, Xu $\mathrm{CB}$ : Vascular endothelin ET(B) receptor-mediated contraction requires phosphorylation of ERK1/2 proteins. Eur J Pharmacol 2006; 538:124-131.

20 Dreja K, Bergdahl A, Hellstrand P: Increased store-operated $\mathrm{Ca}^{2+}$ entry into contractile vascular smooth muscle following organ culture. J Vasc Res 2001;38:324-331.

21 Alioua A, Mahajan A, Nishimaru K, Zarei MM, Stefani E, Toro L: Coupling of c-Src to large conductance voltage- and $\mathrm{Ca}^{2+}$-activated $\mathrm{K}^{+}$channels as a new mechanism of agonist-induced vasoconstriction. Proc Natl Acad Sci USA 2002;99:14560-14565.

22 Weigand L, Foxson J, Wang J, Shimoda LA, Sylvester JT: Inhibition of hypoxic pulmonary vasoconstriction by antagonists of store-operated $\mathrm{Ca}^{2+}$ and nonselective cation channels. Am J Physiol Lung Cell Mol Physiol 2005;289:L5-L13.

23 Wijetunge S, Hughes AD: Src family tyrosine kinases mediate contraction of rat isolated tail arteries in response to a hyposmotic stimulus. J Hypertens 2007;25:1871-1878.

24 Wijetunge S, Lymn JS, Hughes AD: Effects of protein tyrosine kinase inhibitors on voltage-operated calcium channel currents in vascular smooth muscle cells and pp60(csrc) kinase activity. Br J Pharmacol 2000;129: 1347-1354.

25 Umemori H, Inoue T, Kume S, Sekiyama N, Nagao M, Itoh H, Nakanishi S, Mikoshiba K, Yamamoto T: Activation of the G protein $\mathrm{Gq} / 11$ through tyrosine phosphorylation of the alpha subunit. Science 1997;276:18781881.

-26 Hisatsune C, Nakamura K, Kuroda Y, Nakamura T, Mikoshiba K: Amplification of Ca2+ signaling by diacylglycerol-mediated inositol 1,4,5-trisphosphate production. J Biol Chem 2005;280:11723-11730.

27 Ozdener F, Dangelmaier C, Ashby B, Kunapuli SP, Daniel JL: Activation of phospholipase Cgamma2 by tyrosine phosphorylation. Mol Pharmacol 2002;62:672-679.

28 Rumenapp U, Schmidt M, Olesch S, Ott S, Eichel-Streiber CV, Jakobs KH: Tyrosinephosphorylation-dependent and rho-protein-mediated control of cellular phosphatidylinositol 4,5-bisphosphate levels. Biochem J 1998;334:625-631
29 Kawanabe Y, Hashimoto N, Masaki T: Role of phosphoinositide 3-kinase in the nonselective cation channel activation by endothelin-1/endothelinB receptor. Am J Physiol Cell Physiol 2003;284:C506-C510.

30 Moneer Z, Pino I, Taylor EJ, Broad LM, Liu Y, Tovey SC, Staali L, Taylor CW: Different phospholipase-C-coupled receptors differentially regulate capacitative and non-capacitative $\mathrm{Ca} 2+$ entry in $\mathrm{A} 7 \mathrm{r} 5$ cells. Biochem J 2005;389:821-829.

$\checkmark 31$ Albert AP, Large WA: Signal transduction pathways and gating mechanisms of native TRP-like cation channels in vascular myocytes. J Physiol 2006;570:45-51.

-32 Peppiatt-Wildman CM, Albert AP, Saleh SN, Large WA: Endothelin-1 activates a Ca2+permeable cation channel with TRPC3 and TRPC7 properties in rabbit coronary artery myocytes. J Physiol 2007;580:755-764.

33 Magnusson MK, Halldorsson H, Kjeld M, Thorgeirsson G: Endothelial inositol phosphate generation and prostacyclin production in response to G-protein activation by AlF4. Biochem J 1989;264:703-711.

$>34$ Huber C, Saffrich R, Anton M, Passreiter M, Ansorge W, Gorgas K, Just W: A heterotrimeric $\mathrm{G}$ protein-phospholipase A2 signaling cascade is involved in the regulation of peroxisomal motility in CHO cells. J Cell Sci 1997; 110:2955-2968.

-35 Sallese M, Mariggio S, D’Urbano E, Iacovelli L, De Blasi A: Selective regulation of Gq signaling by $\mathrm{G}$ protein-coupled receptor kinase 2: direct interaction of kinase $\mathrm{N}$ terminus with activated galphaq. Mol Pharmacol 2000;57:826-831

36 Morel N, Godfraind T: Selective interaction of the calcium antagonist amlodipine with calcium channels in arteries of spontaneously hypertensive rats. J Cardiovasc Pharmacol 1994;24:524-533.

37 Fleischhacker E, Esenabhalu VE, Holzmann S, Skrabal F, Koidl B, Kostner GM, Graier WF: In human hypercholesterolemia increased reactivity of vascular smooth muscle cells is due to altered subcellular Ca2+ distribution. Atherosclerosis 2000;149:33-42.

$\checkmark 38$ Bae YM, Kim A, Lee YJ, Lim W, Noh YH, Kim EJ, Kim J, Kim TK, Park SW, Kim B, Cho SI, Kim DK, Ho WK: Enhancement of receptor-operated cation current and TRPC6 expression in arterial smooth muscle cells of deoxycorticosterone acetate-salt hypertensive rats. J Hypertens 2007;25:809-817.

39 Rice DC, Dobrian AD, Schriver SD, Prewitt RL: Src autophosphorylation is an early event in pressure-mediated signaling pathways in isolated resistance arteries. Hypertension 2002;39:502-507.

40 Beaucage P, Iglarz M, Servant M, Touyz RM, Moreau P: Position of Src tyrosine kinases in the interaction between angiotensin II and endothelin in in vivo vascular protein synthesis. J Hypertens 2005;23:329-335. 